\title{
Latin American public opinion vis-à-vis regional integration (1995-2018)
}

\author{
La opinión pública latinoamericana frente \\ a la integración regional (1995-2018)
}

\author{
María Victoria Alvarez ${ }^{* *}$
}

\begin{abstract}
Literature on opposition to regional integration has concentrated on the European Union (EU). So far, very few systematic attempts have been pursued to explain opposition to regional integration in Latin America or to identify its main influential factors. Based on Latinobarometer surveys, two main findings emerge from this paper. First, it confirms that opposition to regional integration is not a generalised attitude among Latin Americans. Secondly, the way in which citizens across Latin America evaluate regional integration is strongly influenced by the same predictors as in the EU. Together, citizens' assessments of economic performance (both at the individual and national level) enjoy a preponderance to account for their position regarding regionalism. Others variables, i.e. age, ideological position, and level of education have a more limited explanatory value while occupation is not significant. Thus, economic variables such as citizens' perceptions of their national and individual economy have proven to be directly linked to support for/opposition to economic integration.
\end{abstract}

The author acknowledges the Laboratory for Interdisciplinary Evaluation of Public Policies (LIEPP) (Sciences Po Paris) for funding this research project.

* PhD in International Relations (National University of Rosario, Argentina, UNR); Master's degree in Integration and International Cooperation (UNR Argentina and K.U.Leuven University, Belgium); and postgraduate degree in European Union Law and European Economic Studies (Paris I Panthéon - Sorbonne, France). Associate Professor at the Department of Political Science and International Relations (DPScIR) - UNR. Correo electrónico: maria. alvarez@fcpolit.unr.edu.ar ORCID: https://orcid.org/0000-0002-2203-5082. Recibido: 15 de agosto de 2020. Modificado: 2 de junio de 2021. Aceptado: 30 de junio de 2021. 
Keywords: Regional integration - Public opinion - Opposition - Latin America.

\section{RESUMEN}

La literatura sobre la oposición a la integración regional se ha centrado en la Unión Europea (UE). Muy pocos han sido los intentos para explicar la oposición a la integración en América Latina o para identificar los factores que la influyen. Este estudio está basado en encuestas Latinobarómetro, y produce dos hallazgos principales. Confirma que la oposición a la integración regional no es una actitud generalizada entre los latinoamericanos. Y la forma en que los ciudadanos de América Latina evalúan la integración regional está fuertemente influenciada por los mismos predictores que en la UE. Las evaluaciones de los ciudadanos sobre el desempeño económico, tanto a nivel individual como nacional, gozan de una preponderancia para dar cuenta de la opinión relativa al regionalismo. Otras variables, como la edad, la posición ideológica y el nivel de educación, tienen un valor explicativo más limitado, mientras que la ocupación no es significativa. De esta manera, las variables económicas, como la percepción de los ciudadanos sobre su economía nacional e individual, han demostrado estar directamente vinculadas al apoyo/oposición a la integración económica.

Palabras clave: Integración regional - Opinión pública - Oposición - América Latina. 


\section{INTRODUCTION}

Outside Europe, nowhere but in Latin America have integration attempts and thinking developed so extensively across space and so consistently over time ${ }^{1}$.After the Second World War, Latin American efforts at regionalism have been pursued through different waves. The most recent one, post-liberal or post-hegemonic regionalism, is now being dismantled, after a decade coexisting with projects like the Southern Common Market (Mercosur) or the Andean Community and seeing how the Pacific Alliance gains momentum.

In this particular context, it is more important than ever to study the opposition to regional integration and their implications. The study of opposition to regional integration is relevant not only due to its political implications but also because it helps explain citizens' basic ways of thinking about it. Indeed, such analysis can shed light on the integration process as such as well as on the dissenting actors.

This research relies on quantitative methods and a comparative framework. Comparative integration studies are as old as integration

1 Note that regionalism can be seen as an umbrella concept, covering a multiplicity of distinct phenomena. Hurrell (1995) enumerates five of these, arguing that none should be given the exclusive use of the term: regionalization; regional awareness and identity, regional interstate cooperation; state-promoted regional integration; and regional cohesion. Thus, regional integration is perceived as a type of regionalism. projects. European Union (EU) studies emerged from the efforts of intellectuals who used the European case as a basis to develop a general theory of regional integration. In addition, integration theory arrived in Latin America through the impulse of these very same neofunctionalist scholars such as E. Haas and P. Schmitter who first developed grand theories of the integration process in Europe (Malamud,2010; Warleigh-Lack and Rosamond, 2010).

Such a comparative framework has great methodological benefits because it liberates from the " $\mathrm{N}=1$ " problem, particularly infamous among EU scholars who tend to be parochially European in their focus (Warleigh-Lack and Rosamond, 2010). We will therefore benefit by using the European experience in comparative regional integration studies but by using the Latin American case to nuance hypothesis developed exclusively in the EU case so far.

Until now, the literature on resistance to regional integration has concentrated on the EU. Research has developed exponentially in order to understand and explain the variety of attitudes of actors towards integration but with an exclusive EU focus. This is not surprising since the $\mathrm{EU}$ is the most institutionalized case of regional integration and the one that engendered complex and highly visible oppositions at both the mass and elite levels.

However, so far, very few systematic attempts have been pursued to study 
opposition or resistance to regional integration in Latin America. This should not come as a surprise at least for three reasons. First, Latin American regionalism is mainly an elite-driven or top-down phenomenon relying on both a generally positive opinion at the mass level and a quasi-monolithic pro-integration propensity among political elites which incarnates a type of intergovernmentalism, "interpresidentialism” (Malamud 2003). Second, low rates of mobilization are found on regional integration issues compared to other policy issues ${ }^{2}$; and finally, public opinion surveys have not developed extensively in the region.

It is acceptable to claim that Europe and other regions are not 'comparable' and therefore require different concepts and frameworks. Indeed, comparing the EU with other forms of regionalism highlights the difficulty faced by scholars when moving across the divide separating advanced industrial states from developing countries/emerging economies (Söderbaum 2013).

Too often regional specialization tends to lead scholars to develop conceptual toolboxes and theories that are developed from/for their own 'region', without really trying to engage

2 Over the years, there have been demonstrations against potential multilateral trade agreements-especially in sectors such as agriculture, labor unions and other social organizations. Nevertheless, we are not interested in studying the opposition to Free Trade Agreements (FTAs) but to regional schemes. other cases or competing discourses. Such parochialism prevents the development of a more general and universal discourse. It prevents scholars from recognizing that they may be analyzing similar phenomena but with different languages and conceptualizations in different regions (Söderbaum, 2013).

Nonetheless, a comparison between the European and the Latin American cases can be particularly fruitful to have an in-depth understanding of the resistances engendered by regional integration and of their consequences for the legitimacy of the integration process despite the substantial differences in historical experiences, social and economic structures, geo-strategic location and political regimes. Indeed, although each case of regional integration is obviously different in terms of institutionalization, context and political culture, such differences are usually exaggerated and do not in themselves preclude comparative analysis (Söderbaum,2009). Finally, as noted by A. Malamud (2010), Latin America has been an interesting laboratory for scholars on regionalism to test hypotheses drawn from the European experience on various issues.

Thus, as correctly pointed out by Breslin and Higgott, "when conducted properly, the comparative approach is an excellent tool ... it is a key mechanism for bringing area studies and disciplinary studies together, and enhancing both. It provides new ways of thinking about the case studies whilst at the same time allowing for 
the theories to be tested, adapted and advanced" (2000: 341).

This article examines the opposition to regional economic integration among public opinion in Latin America. Our approach is different from standard literature on public opinion since we tackle the question from a rather "negative" perspective: we focus on opposition and not support. The reason for this theoretical and methodological choice is connected to the fact that while regional integration projects continue to be largely elite-driven, "in democracies, public opinion can count a great deal, and a strong opposition to integration might well spell the end of the regionalist movement in Latin America" (Seligson,1999: 130). In times when Latin American regionalism is complex, at times contradictory and even chaotic (Van Klaveren, 2018), it is clear that the probability that Latin American governments will move forward or turn their backs on the integrationist project depends today far more on public opinion than it did in the authoritarian past (Seligson, 1999).

Therefore, we prefer an approach that emphasizes the opposition dimension of public attitudes toward integration. Since different assumptions may be chosen to illuminate different aspects of mass attitudes vis-àvis regional integration, however, the two perspectives - support and opposition - and their concomitant narratives are complementary rather than mutually exclusive.

The remainder of this article proceeds as follows: in the first section, it briefly discusses some basics about Euroscepticism/opposition within the field of EU studies and political science. It continues by offering a synopsis of the (rather scarce) literature on Latin American public opinion on regional integration. The third section develops the analytical framework to apply to the Latin American case and the subsequent section presents a succinct appraisal of the determinants of public opinion visà-vis regional integration based on the vast EU literature. This is followed by a presentation of hypotheses, data and methods. Next, the article introduces the results from our study, whereas the final section offers some conclusions. 


\section{SOME basics About EurosCePticism/opposition to THE EUROPEAN INTEGRATION PROCESS}

Opposition to the European integration process has been a marginal and even a "taboo" issue for scholars. Historiography of European integration has overlooked manifestations of conflict and little attention has been devoted to political and social resistances to EU integration within and beyond national states (Crespy and Verschueren, 2009). Of course, the failure of the European Defense Community or the 'empty chair crisis', for example, appeared in books devoted to the history of European integration. But overall "The federalist narrative, which dominated the European historiography from the 1940s to the 1970s, generated a linear and finalist history of European integration. This historical lecture tended to play down conflicts and breakdowns while over-emphasizing the continuity of integration through a functionalist perspective" (Crespy and Verschueren, 2009: 379) ${ }^{3}$.

Indeed, European integration was studied almost exclusively by Europhiles. During the first decades of its existence, opponents to the European project were understood by most of those studying European integration simply to be "on the wrong side of

3 "But the social and political forces carrying resistances to integration are not considered and there is no reference book which tackles the issue with a broad perspective" (Crespy and Verschueren, 2009: 380). history", and therefore of little importance as objects of study (Katz, 2008: 152).

However, many scholars have embraced the assumption that the debates over the Maastricht treaty in the 1990s have triggered the end of a 'permissive consensus' which had so far prevailed (Lindberg and Steingold, 1970). The broad picture is that the end of the 'permissive consensus' - the historical elite consensus over Europe was in favor of European integration and public opinion was quiescent- has given rise to a 'constraining dissensus' (Hooghe and Marks, 2008).

The change in mood towards European integration that occurred in many EU countries during the 1990s and 2000s was labelled as 'Euroscepticism. The term Euroscepticism is a catchall generic label for negative attitudes to the EU. As Flood argues, "Euroscepticism remains a somewhat elusive phenomenon with unclear contours and borderlines"(Flood,2002:2): it can be used to refer "to Greek communists, Hungarian neo-Nazis, Dutch Christian conservatives, Greens, farmers, workers and even national institutions" (Leruth, Startin and Usherwood, 2018: 4). This diversity reflects the absence of a commonly agreed definition of Euroscepticism. Even the terms that intend to play as synonyms are debatable.

Euroscepticism has proven highly elusive. First, Euroscepticism is 
a dynamic phenomenon, which makes it difficult to apprehend: it has changed over time as it has evolved with the integration process itself (Leconte, 2010: 4). Second, numerous actors may manifest Euroscepticism: citizens, political parties, the media, national institutions and civil society. The phenomenon can be studied from different perspectives, depending on which actor one places the focus on. For instance, there is an important body of literature on Euroscepticism in public opinion (Franklin et al.,1995; McLaren, 2006, among others).

Studies on the opposition to European integration, however, have not defined or characterized the object of that opposition. Most of the literature has excluded the question of what kind of actor the EU is (or wants to be) on which Euroscepticism revolves. In other words, we can ask what "opposition to Europe" means.

The notion of Euroscepticism is rather incompatible with an exercise of comparison with the Latin
American experience. The literature linked to opposition or dissatisfaction with European integration is exclusively connected to the EU and their conceptual frameworks have no intention to be applied in other contexts.

However, what might be missing here is the possibility to distinguish between different moments in the process of European integration. As we have noted, Euroscepticism never stands still. Focusing on its dynamic nature, opposition to European integration has evolved in parallel to the process itself.

Thus, one can argue that the meaning of Euroscepticism varies across time (Leconte, 2010), as the policy agenda changes (Hix, 2007). In this sense, opposition to regional integration in Latin America could mirror the hostility to the European project in its first stages, when the project was an economic enterprise aiming at integrating markets through trade liberalization and free movement of factors of production.

\section{Reviewing the (SCARCE) LATIN American literature}

Most of the literature devoted to Latin American regionalism stresses the role of pro-integration forces and relativizes the voices of opposition. According to Rivarola Puntigliano and Briceño-Ruiz,"Despite the hurdles, integration remains a firm issue in the official agenda of Latin American countries, and regardless of ideological divisions, no government rejects the integration idea" (2013:3).

Some authors acknowledge the resistance to pursuing further integration as an important feature of the internal political debates in each country -in some cases fearing the hegemonic role of Brazil, in others trying to avoid a linkage to any kind 
of supranational dimension or diversion of international trade (Rivarola Puntigliano, 2013)—. However, in general, the literature tends to ignore opposition.

With the exception of the North American Free Trade Agreement (NAFTA) and the Free Trade Area of the Americas (FTAA) initiative, the role of public opinion in regional economic schemes has been largely devoid of study in the region. Latin Americans' support of/opposition to integration has not been substantially explored especially in terms of multivariate analysis. Some rare exceptions are Seligson (1999), Jara Ibarra (2014) and Deutschmann and Minkus (2018). Seligson (1999) examined support for economic regional integration in seventeen Latin American countries using only 1996 Latinobarometer data and identified a range of micro-level predictors. His article, however, is now obsolete. The first attempt to assess factors that affect Latin American people's opinions on regional integration was conducted by Jara Ibarra (2014), who applied multilevel models to 2009 Latinobarometer data. However, by looking at only one point in time, the study is not able to discern any longitudinal trends (Deutschmann and Minkus, 2018).

As Deutschmann and Minkus (2018) correctly point out, other studies are limited to specific countries: Davis, Gabel and Coleman (1998) studied public support for Central American integration in Costa Rica and El Salvador; Estrades (2006) examined support for Mercosur among Uruguayans, and Stiller
Titchener (2010) scrutinized Bolivians' attitudes toward cooperation with neighboring countries and knowledge of regional integration efforts.

The application of time series analysis has brought this literature a significant step forward, especially through technical studies conducted by the Institute for the Integration of Latin America and the Caribbean (INTAL in Spanish) of the Inter-American Development Bank (IDB) in association with Latinobarometer. For example, Barral Verna, Basco and Garnero (2020) analyzed the opinion of Latin American citizens in relation to support for political integration, democracy, and its institutions, based on the 2018 Latinobarometer survey. The document also took into account the results of surveys from previous years and correlated them with objective indicators.

Instead of focusing on a particular country or a small amount of surveys, our longitudinal analysis includes all countries and each and every one of the Latinobarometer surveys where the integration question was incorporated. In this sense, this research adds to the still limited literature on public opinion on regionalism in Latin America since, to the best of our knowledge, no previous study has attempted to cover this lengthy period of time. Even if Deutschmann and Minkus study (2018) gathers 106,590 respondents, we have recorded 147,294 observations from the first 1995 Latinobarometer to the last one in 2018, which makes it in the largest study on Latin American public opinion on regionalism so far. 
As we point out below, there are some important shortcomings associated with the use of Latinobarometer surveys. The Latinobarometer lacks three years: 1999, 2012 and 2014, and unlike Eurobarometer, not all standard questions in the Latinobarometer recur over long periods of time. The question about popular support for integration in Latin America disappears from the questionnaire in several surveys. Even acknowledging this important gap a longitudinal study was chosen to obtain further comprehensive information and avoid the constraints and weaknesses of looking at one individual survey.

\section{ANALYTICAL FRAMEWORK}

Integration processes in Latin America are mainly free trade endeavors: a clear preference for intergovernmentalism and low levels of institutionalization, as well as for preserving sovereignty and autonomy in the national realm. Latin American integration governance is driven by collective intergovernmental presidentialism. "These features are independent of ideological cleavages, national leaderships, and political cycles"(Sanahuja, 2017: 118).

Latin American governments have focused only in establishing an economic interregional interchange "whereas public opinion has been completely neglected" (Manenteau-Horta 1979 as cited in Jara Ibarra, 2014: 38). Although as from the 2000s the integration process debate has gone beyond the economic dimension to include social issues - especially in the Southern Cone-, the latter still require further elaboration and presence within both the political and the academic discussion in Latin America.

We startout with the basic argument that in the case of Latin American regionalism it is not an increase in the authority that generates controversiality (De Wilde and Zürn, 2012), but rather the governments' attempts to open national markets and liberalize international trade. This is so since in the Latin American case there is no such a move from a market integration project to a political union as in the EU. Region-building in Latin America is driven as much by political as economic factors although "issues of trade and investment appear to dominate the policy agenda" (Grugel, 2006: 215).

As we have appreciated in section I, the notions of Euroscepticism do not suit the parameters for a comparative exercise. The complexity of the EU system and its policies add to this challenge. What might be missing here is the possibility to distinguish between different moments in the process of European integration. As we have noted earlier, focusing on its dynamic nature, opposition to European integration has evolved in parallel to the process itself.

Resistance to the project of the common market in the 1950s is not comparable to the opposition to 
political integration (with an EU citizenship, a common currency and a common foreign and defense policy) embodied in the Maastricht treaty in the 1990s. In the first period, hostility to the European project was expressed either because integration was regarded as a capitalist project-where member states were obliged to liberalize their markets and open up to capital mobility-and/or because it was seen as being incompatible with national sovereignty (Leconte, 2010).

In this sense, opposition to regional integration in Latin America could mirror the criticism to the European project in its first stages, when the project was an economic enterprise aiming at integrating markets through trade liberalization and free movement of factors of production. Since integration processes in Latin America have not evolved towards supranationality or other complex forms of governance, we can consider them as economic endeavors with practically unchanging goals, unlike the EU. Thus, in the Latin American case, we focus on opposition to economic integration.

We avoid looking into the principles upon which the integration process is based, the government or its policies on the integration realm. Rather, we focus on the integration process as a whole. In particular, this article examines the opposition to regional economic integration in Latin America among public opinion and, more importantly, the factors that can be identified to determine citizens' attitudes towards it. Importantly, it was not possible to investigate public support for each sub regional scheme in Latin America. Instead, the analysis was based upon the generic notion of "economic integration" 4
4 Note that 2008, 2009, 2010, 2016 and 2018 Latinobarometer surveys not only ask interviewees about their attitudes on economic integration, but also on political cooperation or political integration among Latin American countries. This last question was excluded from our analysis in order to maintain its homogeneity and coherence. 


\section{Predictors of public opinion VIS- $\grave{A}-$ VIS Regional INTEGRATION}

Public opinion plays a prominent role in political contestation over the EU. Even if neglected for decades when a 'permissive consensus' (Lindberg and Scheingold, 1970) prevailed, public opinion started to manifest disapproval over European integration and a 'constraining dissensus' emerged (Hooghe and Marks, 2008), as we have noted above. In particular, the 1992 rejection by Danish voters of the Maastricht treaty showed that without public support, progress on the integration process could be suspended or even reversed (Seligson, 1999).

Empirical research has shown mainly four factors influencing the development of opposition attitudes towards European integration: cost-benefit analysis of EU accession and membership - the utilitarian factors, fear of the impact of the integration upon the national identity - the identity factors, distrust in the supra-national institutions and the perceived threats to national sovereignty - the political factors and hostility towards the cultural and societal model of the EUthe cultural factors (Leconte, 2010; McLaren, 2006, 2007; Gabel, 1998; Gabel and Palmer, 1995).

From a utilitarian perspective, generic support for European integration is determined by a rational costbenefit analysis: those who benefit economically from European integration (particularly trade liberalization) are supportive, whereas those who stand to lose are more hostile (Gabel and Palmer, 1995; Gabel, 1998; McLaren, 2006). In fact, utilitarian theory is reliant on self-interested or macro explanations of political attitudes, and suggests that citizens are more likely to support integration if it results in a net benefit to the national economy or to their own pockets (Eichenberg and Dalton, 1993; Gabel, 1998; Gabel and Palmer, 1995).

Gabel and Whitten (1997) measured integration support by taking two sets of economic indicators as independent variables, objective macroeconomic variables such as inflation, unemployment and Gross Domestic Product (GDP) -which had already been included in previous models, such as those of Eichenberg and Dalton (1993) - and variables that measure citizens' subjective perceptions of the economy, such as perception of their individual economic situation and their country's economic situation.

Interestingly, the results of the study show that subjective economic variables have more weight in explaining EU support than objective ones. The bottom line is that the more satisfied citizens are with regard to their personal situation and the situation in 
their country, the more they will support the integration process. ${ }^{5}$

Studies of support for the euro have also found that sociotropic economic concerns play a role: citizens in countries that benefit economically, or are perceived to benefit economically, from membership of the EU are supportive of the euro (Hobolt and Wratil,2015). Meanwhile, the Euro crisis has prompted Europeans to reconsider their attitudes towards the $\mathrm{EU}$ and the integration process from a utilitarian perspective (Bargaoanu, Radu and Negrea-Busuioc, 2016).

According to Hooghe and Marks (2004), most researchers have conceptualized European integration as an economic phenomenon: citizens evaluate the economic consequences of European integration for themselves and for the groups of which they are part. Nonetheless, the EU is also a supranational polity and it is plausible that European integration engages national identities. These authors postulate that economic interest variables account for 15 per cent of total variance in public opinion regarding the EU but the influence of these factors is overshadowed by identity variables, i.e. exclusive national identity,

5 Theories of public opinion derived from individual egocentric calculation have been extended in two directions. First, subjective as well as objective factors have been taken into account. Second, sociotropic evaluations concerning one's group (in this case, country) can be theorized alongside egocentric evaluations (Hooghe and Marks, 2005). multiculturalism, and national attachment. Together, these variables explain 20.8 per cent of support for the EU (Hooghe and Marks, 2004).

In this paper we do not consider the explanation for the variation in support for/opposition to European integration which focuses on the threat that European integration can pose to national identity and a country's symbols and values (Hooghe and Marks, 2004; McLaren, 2006) but on socioeconomic factors.

Regarding education, individuals with higher levels of education are more likely to support integration because they are better positioned to take advantage of market liberalization (Gabel, 1998). Meanwhile, different occupational categories would vary in their opinion towards integration. Liberalized labor markets introduce greater competition that can favor some occupations (those with adaptable skills) over others (Gabel, 1998). For example, executives and other white-collar professionals are more likely to support integration than manual workers because they are more likely to be mobile between different industries and sectors (Genna, 2009).

As to income, wealthier individuals are more likely to support integration because capital liberalization will allow them to exploit more investment opportunities (Gabel, 1998). Lower income earners are less likely to support integration because greater 
capital mobility will lessen their bargaining power (Gabel, 1998).

Age, measured in years, is included in the regular set of demographic variables found in surveys. Age would measure the level of flexibility. Older respondents can be less flexible and therefore less supportive of new ideas such as European integration (Genna, 2009).

Political orientation constitutes another major determinant of support for integration (Gabel, 1998). In relation to European integration, Inglehart, Rabier and Reif (1987) showed that right-wing voters were more supportive of the then European Community than were left-wing voters, while Gabel (1998) demonstrated that respondents who identified with a proletariat party were less supportive of integration than those identifying with a bourgeois party.

\section{HyPOTHESES}

As we have established before, Latin America has been an interesting laboratory for scholars on regionalism to test hypotheses drawn from the European experience on various issues. We will then gain benefits by using the Latin American case to nuance hypothesis developed exclusively in the EU case so far.

As we have noted earlier, subjective economic evaluations can be expected to influence public opinion on European integration alongside objective factors. European integration is perceived by most citizens to shape their economic welfare in a general sense. Citizens who feel confident about the economic future -personally and for their country- are likely to regard European integration in a positive light, while those who are fearful will lean towards Euroscepticism (personal economic prospects and national economic prospects) (Hooghe and Marks, 2005). Citizens may be sensitive to their sociotropic or collective economic circumstances, as well as to those that affect them individually. In short, support is given when individuals have favorable egocentric and/or national sociotropic evaluations despite objective economic trends.

\section{- Hypothesis 1: Those who feel that their national economy is not doing well, and that they personally are not doing well economically, are less supportive of integration.}

We also include background variables that have proven to be of relevance to support for European integration, such as an individual's level of educational attainment, occupation and socio-economic position. Immediate 
pocketbook issues clearly have their impact on support of integration, but underlying socio-economic and demographic issues play a role as well. The human capital hypothesis (Gabel, 1998) suggests that less educated people are more skeptical towards the $\mathrm{EU}^{6}$. In Europe, those with higher education are all more supportive of integration than those with lower education. A potential mechanism behind this pattern was proposed by Inglehart (1970a), who argued that "cognitive mobilization" that comes with higher education increases support for European integration. Seligson (1999) found that education clearly stratified support for Latin American economic integration, with the least educated being least favorable. Similar findings have been reported for support for political integration in the region (Jara Ibarra, 2014).

\section{- Hypothesis 2: Those with lower levels of education are less} supportive of regional integration than those who have completed university degrees.

Utilitarian models distinguish between 'losers' and 'winners' of integration and suggest that education and

6 Gabel (1998) claims that liberalization increases the value of the assets possessed by those with higher incomes and higher levels of education. Thus, citizens who possess high levels of 'human capital' (economic assets and education) are less likely to be anti-European than citizens with lower levels of human capital. skills may influence the level of support for the EU. Privileged people are expected to be more favorable to European integration than lower strata categories since the former have better opportunities to act in the international setting (Gabel and Palmer,1995). Highly qualified citizens are more resilient in the EU's neo-liberal economic environment. Citizens with lower or no skill sets find themselves increasingly excluded from full labor market participation. In a simplified assumption, we expect unskilled workers to be against integration and managers or professionals to be supportive. Research in Europe has often found that professionals are more supportive of integration than blue-collar workers (Seligson, 1999).

\section{- Hypothesis 3: Among those} with the lowest level professional occupations, support is lower than among higher-level professional occupations.

The last socio-economic variable linked to support for integration is wealth. Some EU studies find that welloff —as well as more highly educated and highly skilled - citizens are much more likely to favor European integration than Europeans with lower incomes - and lower levels of educational attainment and those who work in the manual, lower-skilled professions-. In particular, studies show that income is likely to affect positive attitudes towards the EU (Guerra, 2018). 
- Hypothesis 4: Those whose socio-economic level is higher are supportive of integration whilst those whose level is lower tend to be against it.

Studies show that age groups can show different patterns across member states, but young people are generally more positive towards the EU integration process (Inglehart, 1970b; Gabel, 1998). However, we do not expect a uniform picture concerning this association. High expectations and low deliveries, or persisting pockets of poverty, can affect attitudes when the EU is mostly perceived as an economic organization (Guerra, 2018). The EU can represent economic benefits at the country and personal levels, but when expectations meet low delivery, the costs of long-term recession can impact on young citizens' attitudes and disengage them from the EU integration project (Guerra, 2018).

\section{- Hypothesis 5: Those who are younger are less supportive than older people.}

The left-right dimension is an enduring marker of ideological positions and continues to structure political choice in domestic politics in Europe. There is a link between left-right self-placement and attitudes towards Europe. While left-right ideology remains a powerful factor in how Europeans view key policy questions, the evidence has not been consistent. For some, right-wing people are more supportive of the EU since they expect profits from European integration owing to liberal market policies (Deflem and Pampel,1996). As for Latin America, Magaloni and Romero (2008) showed that voters of left-wing parties were less supportive of free trade in the 1990s. A note of caution is due here since in contrast to these earlier findings, Jara Ibarra (2014) found that in 2009, left-wing Latin Americans were more supportive of both economic and political integration than the right. More information on left-right self-placement would help us to establish a greater degree of accuracy on this matter.

- Hypothesis 6: Those who tend to align with left-leaning parties are less supportive than those who identify with traditional parties on the right or center. 


\section{Methodology and Data}

As we set out to examine the alleged opposition to Latin American regional integration processes, we need to decide on what type of data to gather in order to test the hypotheses outlined above. Within the region, revealing information can be found in Latinobarometer reports. The Latinobarometer, modelled after the Eurobarometer on which so much European research has been based, covers all of the mainland countries from Mexico to the tip of South America, with the exception of Belize, Surinam and the Guianas.

Opposition to regional integration can be operationalized using a variety of different measures. Latinobarometer database was used for carrying out this study. We have used thirteen of the available surveys on the Latinobarometer official webpage, from the first survey to the last one up to the present (covering the period 1995-2018), which constitutes the largest longitudinal study on the issue to date, to the best of our knowledge.

We rely on the "economic integration" question, which asks respondents if they are in favor of,or against, the economic integration of the countries of Latin America. This question maps whether citizens hold positive or negative views of regional (economic) integration. Individuals are able to choose their position on a fourpoint scale ranging from "very in favor" (1) to "very against" (4). From the first 1995 Latinobarometer to the last one in 2018 we have recorded 147,294 observations.
There are some drawbacks, nonetheless, associated with the use of Latinobarometer surveys. First, the Latinobarometer lacks three years: 1999, 2012 and 2014. Second, unlike Eurobarometer, not all standard questions in the Latinobarometer recur over long periods of time. Even if Latinobarometer conducted several surveys about popular support for integration in Latin America, the question disappeared from the questionnaire in the 2000,2003,2004, 2006, 2007, 2011, 2013 and 2015 surveys.

Third, in the surveys that included this question, the choices for the respondents were slightly different from one survey to another. Sometimes it was formulated in these terms: "Are you in favor or against the integration of your country with other countries in the region?" In other surveys the question was "Are you very much in favor, somewhat in favor, somewhat against or very much against economic integration?"?

Since changes in the wordings of questions make the comparability of the data across time and space problematic, we have recoded the main variable so that lower scores reflect more support for integration, while higher scores indicate greater opposition. We have conducted a logistic regression analysis on a recoded, dichotomous version of our variable. For the analysis we have distinguished between individuals holding positive views of integration

7 The response option for the question was dualistic in the 1995 and 1996 surveys. 
(scoring 1 and 2, here recoded as 0 ), and the rest of respondents (values 3 to 4, here recoded as 1$)$. The "Don't know/ Don't answer" (DK/DA) responses are excluded from the database so that the focus is on those who hold an opinion.

The data analysis then focuses on the factors that relate to higher or lower opposition to integration among Latin Americans, and concludes with a logistic regression analysis of those factors. Specifically this paper analyses the impact of socio-economic and demographic variables (age, years of education, socio-economic situation ${ }^{8}$, and occupation), economic variables such as citizens' perceptions of their national and individual economy, and political variables, which target here only an indicator of self-placement in a left-right ideology scale.

Note that to incorporate the variables of interest in the model, a recoding was needed, since most of them were categorical variables - not quantitative variablesand thus we draw on the creation of dummies. Interestingly, in model 1 that considers all variables, the variable "occupation" was not significant; i.e., the interviewee's occupation did not interfere with the opinion she/he has about regional integration. Then, a new model - model 2- was set disregarding the occupation of the interviewee and all variables were significant. The results of the regression estimations are presented in Table 1.
8 As in many surveys, the Latinobarometer did not ask directly about income since many respondents refuse to answer this question or provide a deceptive answer. A better measure of the respondent's socio-economic level is obtained by the perception of the interviewer.
9 Even though there have been several changes in the wordings of the questions, these are some examples of the questions that tackle our main variables. National economy: In general, how would you describe the present economic situation of the country? Would you say that it is very good, fairly good, about average, fairly bad, or very bad? Individual economy: In general, how would you describe your present economic situation and that of your family? Would you say that it is very good, good, about average, bad or very bad? Education: Years in education of respondent, Occupation: Respondent actual occupation. Age. Socioeconomic level. Very good, good, average, bad, very bad. Ideology: In politics, people normally speak of 'left' and 'right'. On a scale where 0 is left and 10 is right, where would you place yourself? 


\section{RESUlts}

The data analyzed about the opinions of Latin American citizens demonstrate a generic support for integration as shown in previous research (e.g. Seligson, 1999). It is not surprising, however, that attitudes of public opinion towards integration has oscillated over time (Graph 1).Opposition hit the highest point in 1996 and it raised again in 1998 and 2005. However, opposition to economic integration has never reached the 25.5 per cent peak of 1996 again. It is at the present time around 15 per cent.

The most striking result to emerge from the data is that even though the experience with economic integration in Latin America is more limited than in the European case, the individual-level patterns we find in this analysis mirror closely those uncovered in Europe. The results show a strong relationship between Latin Americans' perception of their country's and their own economic situation and support for integration, which is clear from Table 1. Conversely, those most pessimistic about their personal and national economy are against integration. So, $\mathrm{H} 1$ can be confirmed.

Even though the search for the factors that explain these general fluctuant trends are beyond the scope of this paper it is interesting to note that,

Graph 1 Opposition/support economic integration in Latin America (1995-2018)

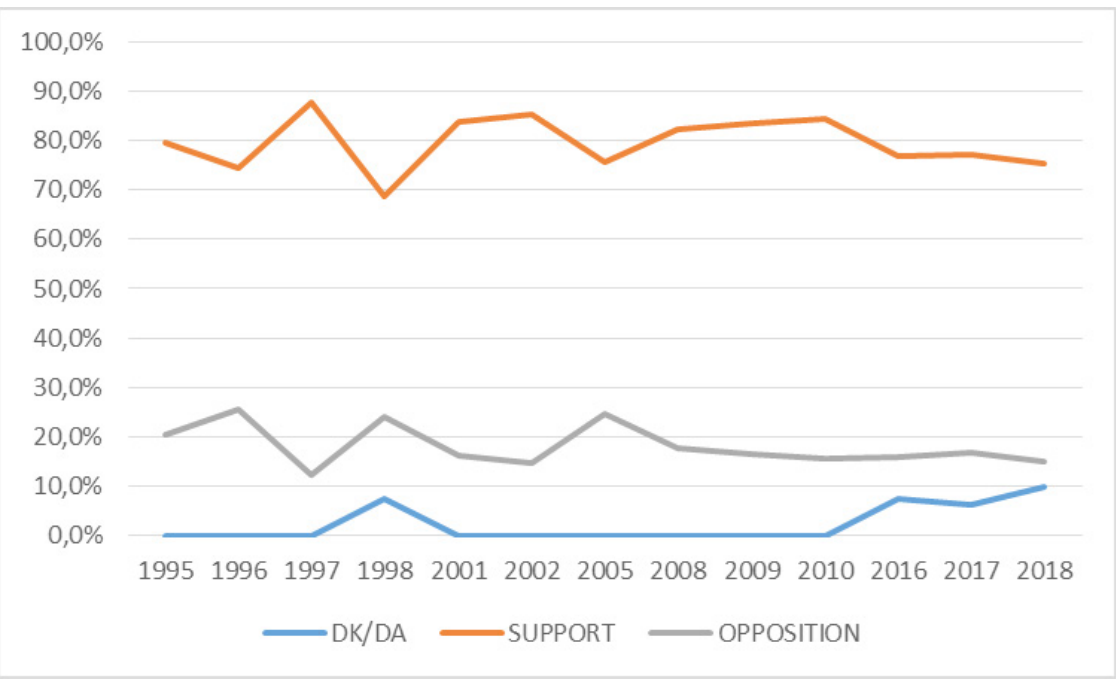

Source: Author's elaboration based on Latinobarometer 


\section{Graph 2 Opposition/support for economic integration in Latin America and global economic trends (1995-2018)}

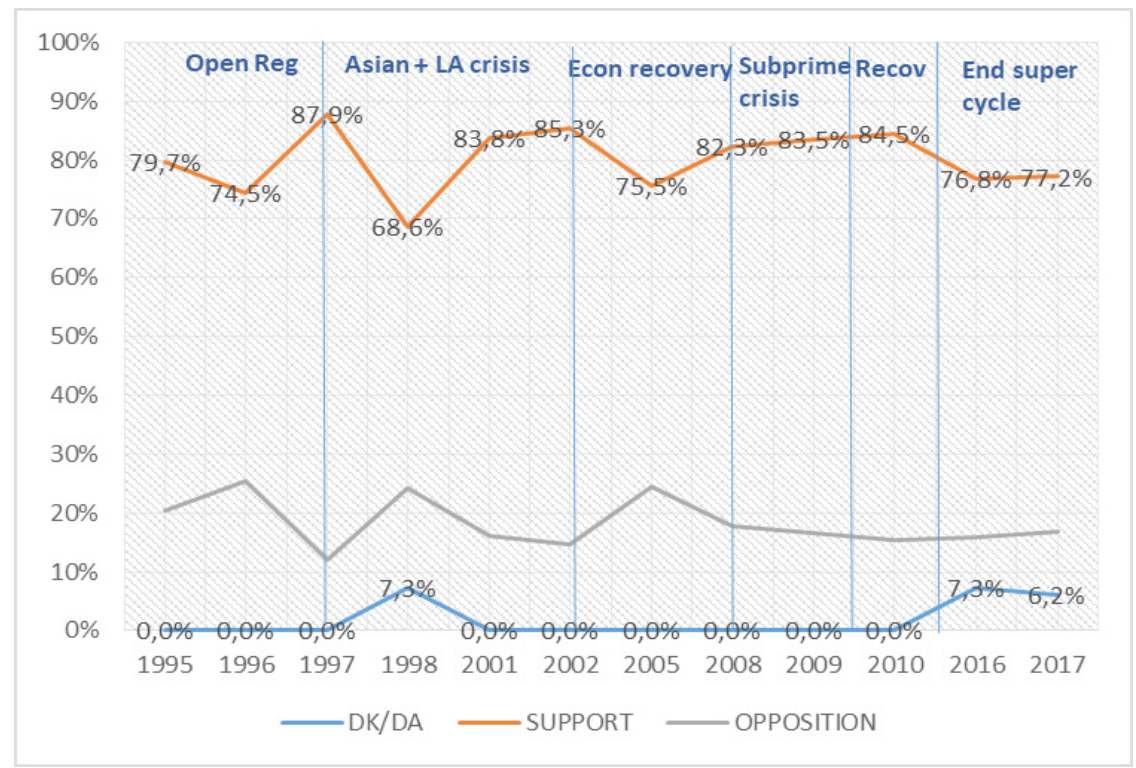

Source: Author's elaboration based on Latinobarometer

surprisingly, the first years of open regionalism overlaps with a decrease in popular support while the super cycle of commodities coincides with negative attitudes towards regional economic integration in 2005. Also, our research shows that the 1998-2001 economic crisis did not substantially bring economic factors back in as an important source of opposition to regional integration.

The partial recovery of Latin American GDP at the end of 2010 has not significantly contributed to a revival of people's trust in regional economic integration, which demonstrates again the gap between the reality presented by the economic indicators and the reality experienced by the citizens of the member states. Thus, individual perceptions play an extremely important role in explaining public opposition to integration in Latin America. Subjective economic evaluations can be expected to influence public opinion on regional integration despite -and not alongside- objective factors.

Some trends, nonetheless, follow expected performances. Although the region made great strides over the period between the 2000s and mid-2010s in poverty eradication, setbacks have occurred since 2015, particularly with regard to extreme 
poverty (ECLAC, 2019). Income inequality decreased considerably in the region between 2002 and 2017, but the pace of this process has slowed in recent years (ECLAC, 2019). The region's poor performance in recent years, coupled with the weak economic cycle, could - though roughlyexplain a decrease in public support to economic integration.

Another way to perceive the same patterns is observing the evolution of GDP in Latin America and general attitudes towards economic integration among Latin American citizens (Graph 3).

To check the robustness of our findings, we have also conducted the analyses with other macroeconomic indicators, such as the GDP growth per capita. We receive similar results. The reason for this is that both macroeconomic indicators -GDP and GDP per capita-are highly correlated with each other (Graph 4).

The other socio-economic and demographic variables shown in the regression analysis are significant predictors. Our study has identified systematic impact on individual-level opposition to integration of literacy (H2), socio-economic level (H4), age (H5) and ideology (H6). Results show a high correlation between those respondents with lower levels of education and whose socio-economic situation is bad and those criticizers

Graph 3 General attitudes towards economic integration and Gross Domestic Product in Latin America (1995-2018)

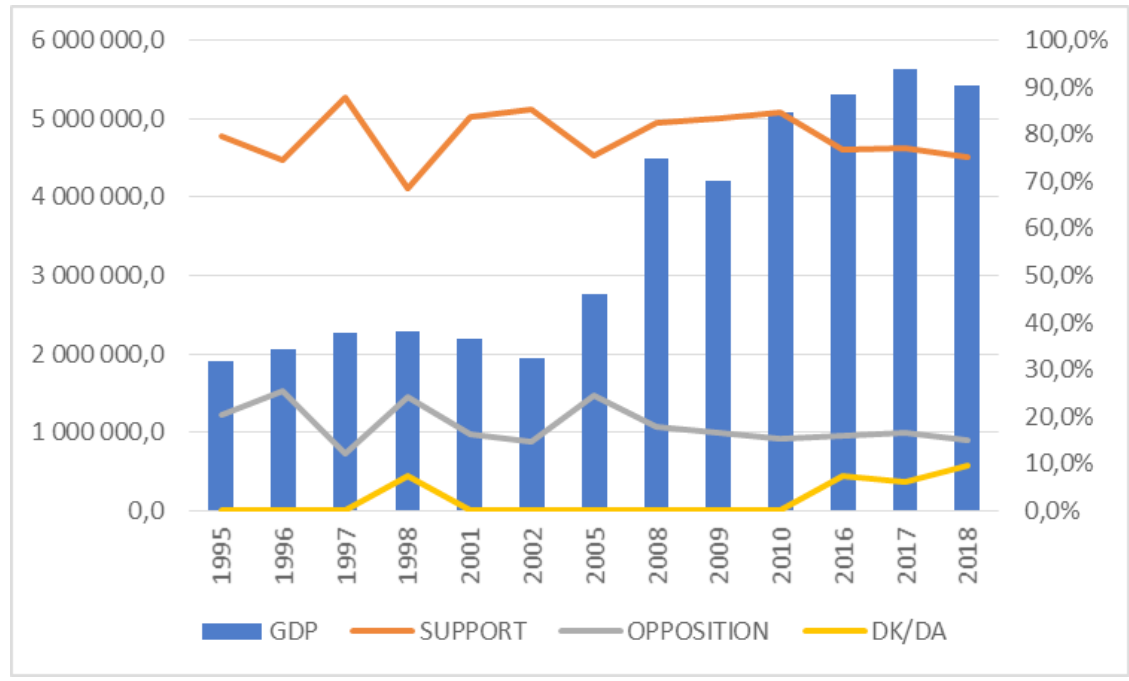

Source: ECLAC, 2019 and author's own statistics based on Latinobarometer surveys 
Graph 4 General attitudes towards economic integration and Per capita Gross Domestic Product in Latin America (1995-2018)

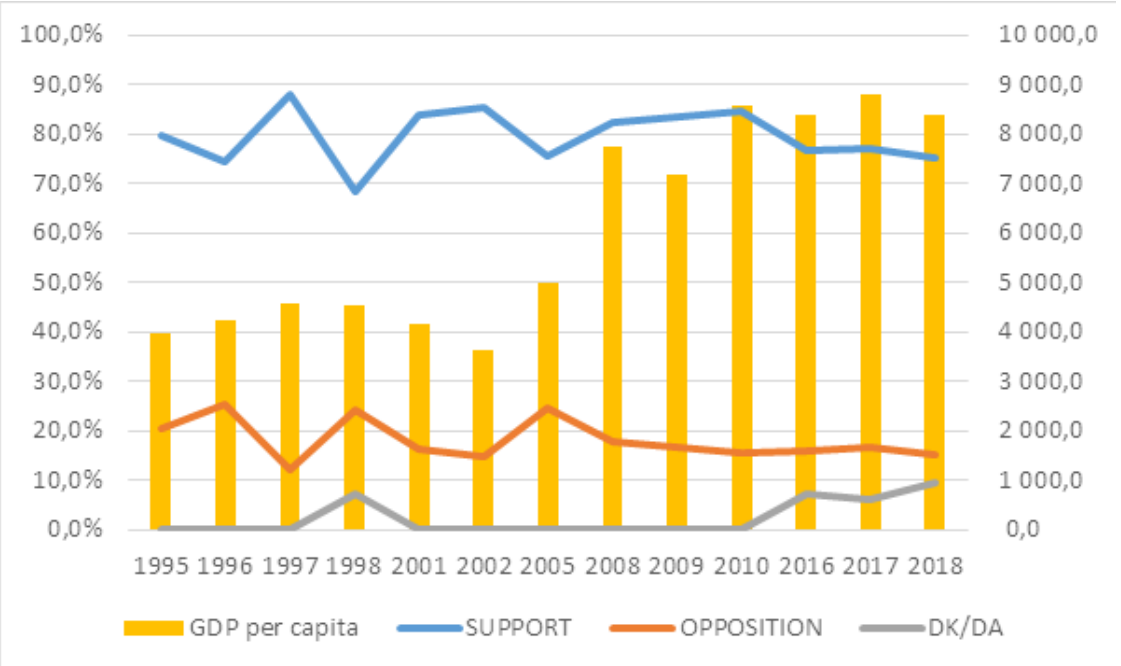

Source: ECLAC, 2019 and author's own statistics based on Latinobarometer surveys

of integration. Also, those who are younger, ${ }^{10}$ and who are in the left of the political spectrum, are less supportive of regional integration.

Overall, the stark differences predicted by the occupation theories $(\mathrm{H} 3)$ are not present in these data. This result supports evidence from previous observations (Seligson, 1999): occupation played only a small role (if at all) in determining support/opposition. It also reflect the results of $\mathrm{Zi}$ zumbo-Colunga and Seligson (1992)

10 With regard to age, these results confirm that opposition to integration among young people prevails for economic integration as recent research has shown (Alvarez, 2020). who found that there does not seem to be a clear skilled-unskilled divide in citizens' attitude about economic endeavors, in their case, FTAs. The lack of an occupation effect is, perhaps, surprising. Our view, however, is that this makes sense in relation to the dominant importance of more direct experiential variables such as the perception of individual economic situation or the country's economic situation. 
Table 1 Determinants of public opinion on economic integration in Latin America

\begin{tabular}{|c|c|c|c|}
\hline & Model 1 & & Model 2 \\
\hline & $<2 e-16 * * *$ & & $<2 \mathrm{e}-16 * *$ \\
\hline $\begin{array}{l}\text { COUNTRY } \\
\text { ECON SIT } 2 \\
\end{array}$ & 0.607353 & \begin{tabular}{|l} 
COUNTRY \\
ECON SIT 2 \\
\end{tabular} & 0.626124 \\
\hline $\begin{array}{l}\text { COUNTRY } \\
\text { ECON SIT } 3\end{array}$ & $1.57 \mathrm{e}-09 \% * *$ & $\begin{array}{l}\text { COUNTRY } \\
\text { ECON SIT } 3\end{array}$ & $1.22 \mathrm{e}-09 \% *$ \\
\hline $\begin{array}{l}\text { COUNTRY } \\
\text { ECON SIT } 4\end{array}$ & $5.24 \mathrm{e}-12 \% *$ & \begin{tabular}{|l} 
COUNTRY \\
ECON SIT 4
\end{tabular} & $5.53 e-12 * *$ \\
\hline $\begin{array}{l}\text { COUNTRY } \\
\text { ECON SIT } 5\end{array}$ & $4.17 \mathrm{e}-15 \%$ & $\begin{array}{l}\text { COUNTRY } \\
\text { ECON SIT } 5\end{array}$ & $5.95 e-15 \% *$ \\
\hline $\begin{array}{l}\text { INDIV ECON } \\
\text { SIT } 2\end{array}$ & 0.144684 & $\begin{array}{l}\text { INDIV ECON } \\
\text { SIT } 2\end{array}$ & 0.134306 \\
\hline $\begin{array}{l}\text { INDIV ECON } \\
\text { SIT } 3\end{array}$ & $<2 \mathrm{e}-16 \% *$ & $\begin{array}{l}\text { INDIV ECON } \\
\text { SIT } 3\end{array}$ & $<2 e-16 * * *$ \\
\hline RIGHT/LEFT 1 & $3.65 \mathrm{e}-09^{* * *}$ & RIGHT/LEFT 1 & $1.43 e-08 * * *$ \\
\hline RIGHT/LEFT 5 & $<2 \mathrm{e}-16^{* * *}$ & RIGHT/LEFT 5 & $<2 e-16 \approx * *$ \\
\hline EDUCATION 2 & 0.607409 & EDUCATION 2 & 0.592513 \\
\hline EDUCATION 3 & 0.868391 & EDUCATION 3 & 0.907137 \\
\hline EDUCATION 4 & 0.500283 & EDUCATION 4 & 0.476648 \\
\hline EDUCATION 5 & $0.003464 \%$ & EDUCATION 5 & $0.004304 \%$ \\
\hline EDUCATION 6 & $0.000719^{* * * *}$ & EDUCATION 6 & $0.000942 * * *$ \\
\hline EDUCATION 7 & $3.92 e-10 \% * *$ & EDUCATION 7 & $6.22 \mathrm{e}-10 * * *$ \\
\hline EDUCATION 8 & $1.19 \mathrm{e}-07 \ldots$ & EDUCATION 8 & $8.12 \mathrm{e}-08 * * *$ \\
\hline EDUCATION 9 & $2.04 \mathrm{e}-10 \% *$ & EDUCATION 9 & $9.36 \mathrm{e}-11 \% * \%$ \\
\hline EDUCATION 10 & $2.29 \mathrm{e}-09^{* * * *}$ & EDUCATION 10 & $1.31 \mathrm{e}-09^{* * * *}$ \\
\hline EDUCATION 11 & $1.68 \mathrm{e}-06 \cdots$ & EDUCATION 11 & $1.16 \mathrm{e}-07^{* * *}$ \\
\hline EDUCATION 12 & $1.34 \mathrm{e}-11 \% * *$ & EDUCATION 12 & $1.40 \mathrm{e}-12 \% * *$ \\
\hline EDUCATION 13 & $<2 e-16 * \cdots *$ & EDUCATION 13 & $<2 e-16^{\cdots \cdots *}$ \\
\hline EDUCATION 14 & $1.00 \mathrm{e}-13$ *** & EDUCATION 14 & $<2 \mathrm{e}-16 \% *$ \\
\hline EDUCATION 15 & $<2 e-16 \cdots *$ & EDUCATION 15 & $<2 e-16 \cdots *$ \\
\hline EDUCATION 16 & $9.21 \mathrm{e}-11 \%$ & EDUCATION 16 & $1.78 \mathrm{e}-12 \% *$ \\
\hline
\end{tabular}




\begin{tabular}{|c|c|c|c|}
\hline EDUCATION 17 & $<2 \mathrm{e}-16 * * *$ & EDUCATION 17 & $<2 \mathrm{e}-16 * * *$ \\
\hline OCCUP2 & 0.224142 & $\begin{array}{l}\text { SOCIO-ECON } \\
\text { LEV } 2\end{array}$ & 0.795091 \\
\hline OCCUP3 & 0.071401 & $\begin{array}{l}\text { SOCIO-ECON } \\
\text { LEV } 3\end{array}$ & $0.000118 \%$ \\
\hline OCCUP4 & $0.000794 \%$ & $\begin{array}{l}\text { SOCIO-ECON } \\
\text { LEV } 4\end{array}$ & $1.09 \mathrm{e}-08 \ldots * \%$ \\
\hline OCCUP5 & 0.581317 & $\begin{array}{l}\text { SOCIO-ECON } \\
\text { LEV } 5\end{array}$ & $6.34 \mathrm{e}-09^{* * * *}$ \\
\hline OCCUP6 & 0.083996 & AGE & $33.52 e-07 \cdots$ \\
\hline OCCUP7 & 0.208857 & YEAR & $<2 e-16 * \cdots *$ \\
\hline OCCUP8 & $2.12 \mathrm{e}-05 \% * *$ & & \\
\hline OCCUP9 & $4.63 e-09^{* * *}$ & & \\
\hline OCCUP10 & 0.648165 & & \\
\hline OCCUP11 & $0.011989 *$ & & \\
\hline OCCUP12 & $<2 \mathrm{e}-16 * \cdots *$ & & \\
\hline $\begin{array}{l}\text { SOCIO-ECON } \\
\text { LEV } 2\end{array}$ & 0.841230 & & \\
\hline $\begin{array}{l}\text { SOCIO-ECON } \\
\text { LEV } 3\end{array}$ & $6.39 \mathrm{e}-06 \ldots$ & & \\
\hline $\begin{array}{l}\text { SOCIO-ECON } \\
\text { LEV } 4\end{array}$ & $2.12 \mathrm{e}-10 \% * \%$ & & \\
\hline $\begin{array}{l}\text { SOCIO-ECON } \\
\text { LEV } 5\end{array}$ & $7.88 \mathrm{e}-10 \% *$ & & \\
\hline AGE & $<2 \mathrm{e}-16 * * *$ & & \\
\hline YEAR & $<2 \mathrm{e}-16 \% *$ & & \\
\hline
\end{tabular}

Source: Author's elaboration based on Latinobarometer surveys

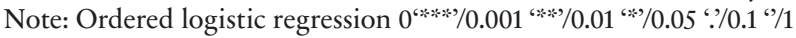

In summary, these results suggest that those interviewed who consider that the economic situation in the country is bad, consider that their individual economic situation is bad, who are young and tend to vote for left parties, are expected to be opposed to economic integration. Those with a basic level of education, and whose socio-economic level is low are also less supportive.

Inversely, individuals that consider that the country economic situation is good, that their personal economic 
situation is good, who are older, and who are in the center or right of the political spectrum, are significantly more supportive of regional integration. Also those who have higher average level of education (measured by years in school), with a very good socio-economic situation are more supportive.

Our study reveals that perceptions of economic individual situation account for 30 per cent-and of national economic situation for 24 per centof total variance in Latin American public opinion regarding regional integration. Together, these variables enjoys a preponderance to account for the position regarding regionalism. Others variables, i.e. age (20 per cent), ideological position (13 per cent), and level of education (13 per cent) have a more limited explanatory value. These results agree with studies that have conceptualized European integration as an economic phenomenon, and therefore considered public opinion as a function of the distributional consequences of market liberalization.

\section{Conclusion}

Regional integration schemes are not all the same. The differences between them are not ontological, but rather of degree - the degree of scope and depth of cooperation and integration, the degree of institutionalization, the degree of supranationality, and state of development. In Latin America, despite national traditions of collective action, public mobilization is weaker.

Until now, the literature on opposition to regional integration has concentrated on the EU. There has not been much systematic research on attitudes towards regional integration in Latin America. We have benefited by using the Latin American case to nuance hypothesis developed exclusively in the EU case so far. After a brief review of the basics about Euroscepticism/opposition to the EU, we argue that this notion is quite incompatible with an exercise of comparison with the Latin American experience. Conceptual categories are exclusively connected to the EU and have no intention to be applied in other regional contexts.

However, Euroscepticism might inform views of regional integration more generally, if focus is placed on its changing nature over time, recalling that the EU has been primarily an economic project driven by the premise of creating a common market in goods, services, labor and capital. Political and economic integration might be differentiated and so is opposition to these dimensions.

The findings from this study intend to contribute to the current literature. Combining the information gleaned from the survey items analyzed, two main conclusions can be drawn. First, 
we confirm that opposition to regional integration is not a generalized attitude among Latin Americans. State-led, presidential-driven integration has been a persistent feature of Latin American integration, as has been the low level of involvement of citizenship.

Secondly, economic variables such as citizens' perceptions of their national and individual economy have proven to be directly linked to support for/opposition to economic integration. Interestingly, the results of the study show that subjective economic variables have more weight in explaining public support than objective ones. This analysis ratifies that the utilitarian model, based on people's perceptions, is the most explanatory factor in the Latin American case. The bottom line is that the more satisfied citizens are with regard to their personal situation and the situation in their country, the more they will support the integration process and vice versa.

The present study lays the ground for future research into other factors rather than utilitarian variables to explain opposition to regional integration in Latin America, such as identity-based arguments. The effect of identity and affective considerations on the public opinion of Latin American countries should be incorporated to move the debate forward. New and more specific questions need to be asked to better map different attitudes -and their causes- so that we have a fuller understanding of the phenomenon.

\section{REFERENCES}

Alvarez, M.A. (2020). “Opposing Regional Integration in Comparative Perspective. Understanding Opposition of Public Opinion to Regional Integration in Europe and Latin America." Sciences Po LIEPP Working Paper 107, March. Paris: Laboratoire interdisciplinaire d'évaluation des politiques publiques.

Barral Verna, Á.; Basco, A.I. \& Garnero, P. (2020). "Entre luces y eclipses: la opinión de los latinoamericanos sobre democracia, instituciones e integración regional”. Technical Note No IDB-TN-1906, Buenos Aires: BID-INTAL.

Bargaoanu, A.; Radu, L. \& Negrea-Busuioc, E. (2016). "The Rise of Euroscepticism in Time of Crisis: Evidence from the 2008-2013 Eurobarometers". Romanian Journal of Communication and Public Relations. Vol. 16 no. 1, pp. 9-23.

Breslin, S. \& Higgott, R. (2000)."Studying Regions: Learning from the Old, Constructing the New"New Political Economy, Vol.5 no.3, November, pp.333-352.

Crespy, A. \& Verschueren, N. (2009) "From Euroscepticism to Resistance to European Integration: An Interdisciplinary Perspective." Perspectives on European Politics and Society, Vol.10 No.3, pp.377-393.

Davis, Ch.; Gabel, M. \& Coleman, K. (1998). "Citizen Response to Regional Integration in the Americas: The Cases of 
Costa Rica and El Salvador". Studies in Comparative International Development Vol. 33 No. 2, pp. 88-109.

Deflem, M. \& Pampel, F. (1996).“The Myth of Postnational Identity: Popular Support for European Unification”. Social Forces, Vol 75 No. 1, pp.119-143.

Deutschmann, E. \& Minkus, L. (2018). "Swinging Leftward: Public Opinion on Economic and Political Integration in Latin America, 1997-2010". Latin American Research Review, Vol 53 No.1, pp. 38-56.

De Wilde, P. \& Zürn, M. (2012). "Can the Politicization of European Integration be Reversed?". Journal of Common Market Studies, Vol. 50, no. s1, pp. 137-153.

Economic Commission for Latin America and the Caribbean (ECLAC) (2020), Statistical Yearbook for Latin America and the Caribbean, 2019 (LC/ PUB.2020/2-P), Santiago.

Economic Commission for Latin America and the Caribbean (ECLAC) (2019). Social Panorama of Latin America, 2018 (LC/PUB.2019/3-P), Santiago.

Eichenberg, R. \& Dalton, R. (1993). "Europeans and the European Community: The Dynamics of Public Support for European Integration". International Organization Vol. 47 No.4, pp. 507-534.

Estrades, C. (2006). "Opinión pública y MERCOSUR: Conocimiento y apoyo de los uruguayos al proceso de integración regional”. Revista Uruguaya de Ciencia Política No. 15, pp. 107-127.

Flood,Ch.(2002,September).Euroscepticism: A Problematic Concept. Paper presented at the UACES 32nd Annual Conference and 7th Research Conference, Queen's University Belfast.

Franklin, M.; Van der Eijk, C. \& Marsh, M. (1995). "Referendum Outcome and Trust in Government: Public Support for Europe in the Wake of Maastricht". West European Politics Vol. 18 No. 3, pp. 101-7

Gabel, M. (1998). "Public Support for European Integration: An Empirical Test of Five Theories”. The Journal of Politics, Vol. 60, No. 2, pp. 333-354.

Gabel, M. \& Palmer, H. (1995).“Understanding Variation in Public Support for European Integration”. European Journal of Political Research, No. 27, pp. 3-19. Gabel, M. \& Whitten, G. (1997)."Economic Conditions, Economic Perceptions, and Public Support for European Integration", Political Behavior Vol.19, No.1, The Economics of Politics in Comparative Perspective Revisited, March, pp. 81-96. Genna, G.M. (2009) Positive country images, trust and public support for European integration. Comparative European Politics, no. 7, pp. 213-232.

Grugel, J. (2006). "Regionalist governance and transnational collective action in Latin America". Economy and Society, Vol. 35 No. 2, pp. 209-231.

Guerra, S. (2018). "Young People and the EU at Times of Crisis" in: Leruth, B.; Startin, N. \& Usherwood, S. (eds.), The Routledge Handbook of Euroscepticism. Abingdon/New York: Routledge, pp. 204-214.

Hix, S. (2007). "Euroscepticism as Anti-Centralization A Rational Choice Institutionalist Perspective”. European Union Politics, Vol. 8 No.1, pp. 131-150. 
Hooghe, L. \& Marks, G. (2008). "A Postfunctionalist Theory of European Integration: From Permissive Consensus to Constraining Dissensus”. British Journal of Political Science, No. 39, pp.1-23.

Hooghe, L. \& Marks, G. (2005). "Calculation, Community and Cues. Public Opinion on European Integration”.European Union Politics, Vol 6 No. 4, pp. 419-443.

Hooghe, L. \& Marks, G. (2004). “Does Identity or Economic Rationality Drive Public Opinion on European Integration?”. Political Science and Politics, Vol. 37 No. 3, pp. 415-420.

Hobolt, S. \& Wratil, Ch. (2015)."Public opinion and the crisis: the dynamics of support for the euro".Journal of European Public Policy, Vol. 22 No.2, pp. 238-256.

Hurrell, A. (1995). Regionalism in theoretical perspective. in Fawcett, L. \& Hurrell, A. (eds.), Regionalism in world politics. Regional organization and international order. Oxford: Oxford University Press.

Inglehart, R. (1970a). “Cognitive Mobilization and European Identity”. Comparative Politics, Vol 3 No.1, pp. 45-70.

Inglehart, R. (1970b). "Public opinion and regional integration”, International $\mathrm{Or}$ ganization, Vol 24 No.4, pp. 764-795.

Inglehart, R.; Rabier, J-R. \& Reif, K. (1987). "The evolution of public attitudes toward European integration: 19701986". Journal of European Integration, Vol. 10, No. 2-3, pp. 135-155.

Jara Ibarra, C. (2014). "Public support for Latin American integration: an econometric model for the assessment of individual and contextual factors". Estudios Internacionales, No.179, pp. 35-60
Katz, R. (2008). Euroscepticism in Parliament: A Comparative Analysis of the European and National Parliaments, in Szczerbiak, A. \& Taggart, P. (eds.),Opposing Europe? The Comparative Party Politics of Euroscepticism Volume 2 Comparative and Theoretical Perspectives. Oxford: Oxford University Press, pp. 151-180.

Leconte, C. (2010). Understanding Euroscepticism. Basingstoke: Palgrave Macmillan.

Leruth, B.; Startin, N. \& Usherwood, S. (2018)."Defining Euroscepticism. From a broad concept to a field of study", in Leruth, B.; Startin, N. \& Usherwood, S. (eds.), The Routledge Handbook of Euroscepticism. Abingdon/New York: Routledge, pp. 3-10

Lindberg, L. \& Scheingold, S. (eds.) (1970). Regional Integration: Theory and Research. Cambridge Mass.: Harvard University Press.

Magaloni, B. \& Romero, V. (2008). "Partisan Cleavages, State Retrenchment, and Free Trade: Latin America in the 1990s”. Latin American Research Review No. 43, pp. 107-135.

Malamud, A. (2003). Presidentialism and MERCOSUR: A Hidden Cause for a Successful Experience, in Finn Laursen (eds.), Comparative Regional Integration: Theoretical Perspectives, pp 53-73. London: Ashgate.

Malamud, A. (2010, July). Conceptos, teorías y debates sobre la integración regional, presented at the V Congreso Latinoamericano de Ciencia Política (ALACIP), Buenos Aires.

McLaren, L. (2006). Identity, Interests and Attitudes to European Integration. Basingstoke: Palgrave Macmillan. 
McLaren, L. (2007). Explaining Mass-Level Euroscepticism: Identity, Interests, and Institutional Distrust. Acta Política, no. 42, pp. 233-251.

Rivarola Puntigliano, A. (2013). "Geopolitics and Integration: A South American Perspective”, in Rivarola Puntigliano, A. $\&$ Briceño Ruiz, J. (eds.), Resilience of Regionalism in Latin America and the Caribbean. Development and Autonomy. New York: Palgrave Macmillan, pp.19-52.

Rivarola Puntigliano, A. \& Briceño-Ruiz, J. (2013). "Introduction: Regional Integration - Linking Past and Present”, in Rivarola Puntigliano, A. \& Briceño Ruiz, J. (eds.), Resilience of Regionalism in Latin America and the Caribbean. Development and Autonomy. New York: Palgrave Macmillan, pp. 1-18.

Sanahuja,J.A. (2017)."Beyond the Pacific-Atlantic divide: Latin American regionalism before a new cycle", in Briceño-Ruiz, J. \& Morales, I. (eds.). Post-Hegemonic Regionalism in the Americas. Toward a Pacific-Atlantic Divide?. Abingdon/New York: Routledge, pp. 99-124

Schneider, S. \& Hurrelmann, A. (2015). "Understanding the Legitimacy of Regional Integration: A Comparative and Mixed-Method Perspective", in Hurrelmann, A. \& Schneider, S., The Legitimacy of Regional Integration in Europe and the Americas. Basingstoke: Palgrave Macmillan, pp. 1-16.

Seligson, M.A. (1999). “Popular Support for Regional Economic Integration in Latin America”. Journal of Latin American Studies, Vol. 31 No. 1, pp. 129-150.
Söderbaum, F. (2013). "What's wrong with Regional Integration? The Problem of Eurocentrism”. RSCAS 2013/64 Robert Schuman Centre for Advanced Studies Global Governance Programme-63, Fiesole: European University Institute. Söderbaum, F. (2009). "Comparative Regional Integration and Regionalism”, in Landman, T. \& Robinson, N. (eds.), SAGE Handbook of Comparative Politics. Thousand Oaks: SAGE, pp. 477-496.

Stiller Titchener, K. (2010). The Viability of South American Regional Integration: Bolivian National Identity in the Integration Process. PhD diss., Oklahoma State University.

Van Klaveren, A. (2018). “El eterno retorno del regionalismo latinoamericano".Nueva Sociedad $\mathrm{n}^{\circ} 275$, pp. 62-72.

Vasilopoulou, S. (2013). "Continuity and Change in the Study of Euroscepticism: Plus ça change?" Journal of Common Market Studies, Vol 51 No.1, pp.153-168. Warleigh-Lack, A. \& Van Langenhove, L. (2010) "Rethinking EU Studies: The Contribution of Comparative Regionalism”. Journal of European Integration, Vol 32 No.6, pp. 541-562

Zizumbo-Colunga, D. \& Seligson, M.A. (2015)."Economic Evaluations and Support for Free Trade in Latin America and the Caribbean", in Hurrelmann, A. \& Schneider, S. (eds.), The Legitimacy of Regional Integration in Europe and the Americas. Basingstoke: Palgrave Macmillan, pp. 117-131. 